\title{
Analiza EKG to nie tylko rola lekarza...
}

\author{
ECG analysis is not only the role of a doctor...
}

\author{
Izabela Milena Poddębska, Dorota Sekuta, Jerzy Krzysztof Wranicz, Iwona Cygankiewicz \\ Klinika Elektrokardiologii Katedry Kardiologii i Kardiochirurgii Uniwersytetu Medycznego w Łodzi
}

\section{Streszczenie}

Choroba Parkinsona jest często opisywaną przyczyną elektrokardiograficznych pomyłek diagnostycznych. Zapisy krzywych w elektrokardiogramie (EKG) interpretowane jako częstoskurcze komorowe lub/i trzepotanie przedsionków sa $\mathrm{w}$ istocie spowodowane drżeniami mięśniowymi. Opisany przypadek dotyczy 59-letniego mężczyzny z chorobą Parkinsona, u którego na podstawie zapisu EKG rozpoznano częstoskurcz z szerokimi zespołami QRS. Pacjenta skierowano do kliniki w celu rozważenia kwalifikacji do implantacji kardiowertera-defibrylatora. Dokładna analiza EKG pozwoliła na weryfikację rozpoznania.

Słowa kluczowe: EKG, choroba Parkinsona, artefakty, częstoskurcz z szerokimi zespołami QRS

Folia Cardiologica 2015; 10, supl. C: 1-3

\section{Wstęp}

Zapis elektrokardiograficzny (EKG) stanowi jedno z podstawowych badań diagnostycznych w codziennej praktyce lekarskiej [1]. Pierwszej, wstępnej analizy EKG dokonuje osoba, która to badanie wykonuje. Bardzo duże znaczenie mają poprawność techniczna rejestracji, ułożenie elektrod, odpowiednie przygotowanie skóry oraz zwrócenie uwagi na aktywność mięśniową badanego. W niniejszej publikacji przedstawiono przypadek 59-letniego mężczyzny z chorobą Parkinsona i rejestracją EKG, która początkowo została zinterpretowana jako częstoskurcz z szerokimi zespołami QRS.

\section{Opis przypadku}

Mężczyzna w wieku 59 lat, z chorobą Parkinsona, gruczolakiem prostaty i chorobą wrzodową żołądka, zgłosił się z powodu bólu brzucha do nocnej pomocy lekarskiej, gdzie wykonano u niego standardowy 12-odprowadzeniowy zapis EKG (ryc. 1). Po analizie zapisu lekarz z przy- chodni skierował pacjenta do szpitala z rozpoznaniem częstoskurczu z szerokimi zespołami QRS. W szpitalu u pacjenta nie występowały objawy. W badaniach laboratoryjnych stwierdzono jedynie nieznaczną hipokaliemię (stężenie jonów potasu 3,6 mmol/l). Badanie echokardiograficzne wykazało dobrą funkcję skurczową lewej komory ([LVEF, left ventricular ejection fraction] 65\%), bez odcinkowych zaburzeń kurczliwości. W kolejnych zapisach EKG wykluczono ostry zespół wieńcowy, nie obserwowano zaburzeń rytmu. W długotrwałej rejestracji EKG uwidoczniono pojedynczą arytmię komorową i nadkomorową. W koronarografii nie stwierdzono przewężeń w naczyniach wieńcowych. Utrzymano pierwotną interpretacje pierwszego zapisu EKG jako częstoskurczu z szerokimi zespołami QRS i skierowano chorego do kliniki w celu oceny wskazań do elektroterapii.

Po ocenie stanu klinicznego pacjenta, jego zapisów EKG (ryc. 2, 3) oraz rejestracji metodą Holtera chorego zdyskwalifikowano z dalszych działań inwazyjnych. Zapis EKG z pomocy lekarskiej uznano za rytm miarowy 


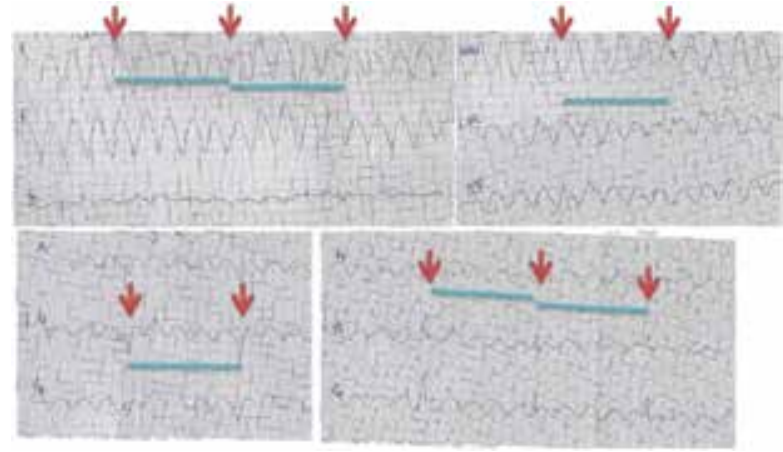

Rycina 1. Standardowy 12-odprowadzeniowy zapis elektrokardiograficzny wykonany podczas wizyty w placówce nocnej pomocy lekarskiej (zespoły QRS oznaczono strzałkami)

z licznymi artefaktami wynikającymi z ruchów kończyn w przebiegu choroby Parkinsona [2].

\section{Ocena zapisów elektrokardiograficznych}

Na rycinie 1 przedstawiono zapis EKG z nocnej pomocy lekarskiej. W odprowadzeniach kończynowych widać równomierne wychylenia przypominające zapis częstoskurczu z szerokimi zespołami QRS. Jednakże dokładna analiza odprowadzeń kończynowych pozwala zauważyć wąskie, regularne zespoły QRS o częstości 58/min. Ten sam przymiar można odłożyć w odprowadzeniach kończynowych. Kolejną myIną interpretacją mogłoby być rozpoznanie trzepotania przedsionków, co sugerują fale widoczne między zespołami QRS w odprowadzeniach V1-V6. Jednak amplituda fali trzepotania przedsionków nie powinna być wyższa niż amplituda zespołów QRS, co ma miejsce w tym przypadku. Lepszej jakości zapisy wykonano w klinice, jednak w nich również widać liczne zakłócenia - zarówno w zapisach spoczynkowego EKG, jak i rejestracji holterowskiej. $\mathrm{Na}$ rycinie 2 załamki $\mathrm{P}$ są dobrze widoczne w odprowadze-

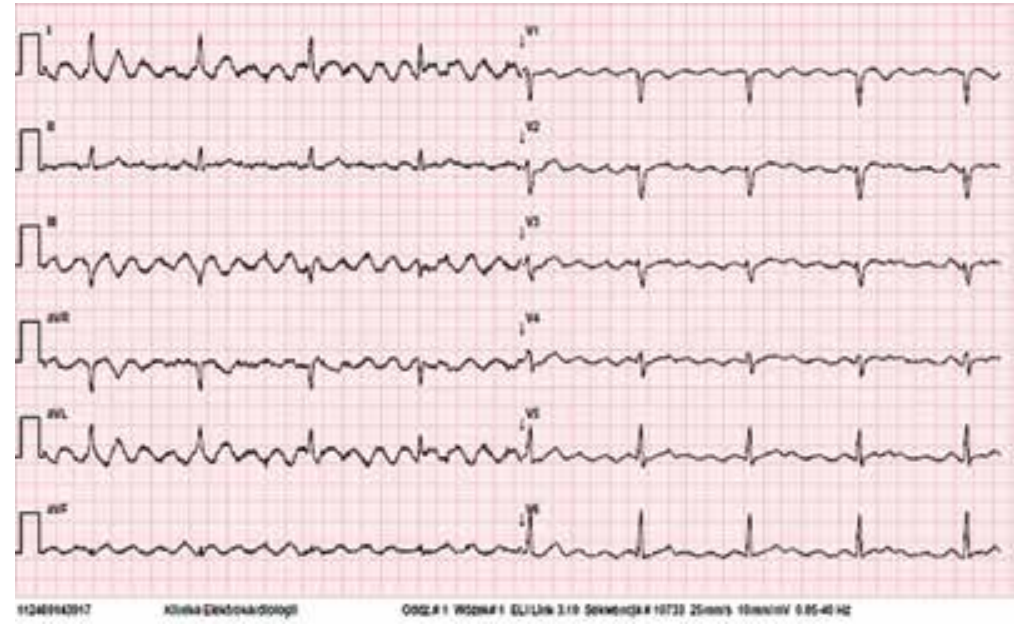

Rycina 2. Standardowy 12-odprowadzeniowy zapis elektrokardiograficzny przedstawiający rytm zatokowy z licznymi artefaktami wynikającymi z drżeń mięśniowych u pacjenta z chorobą Parkinsona

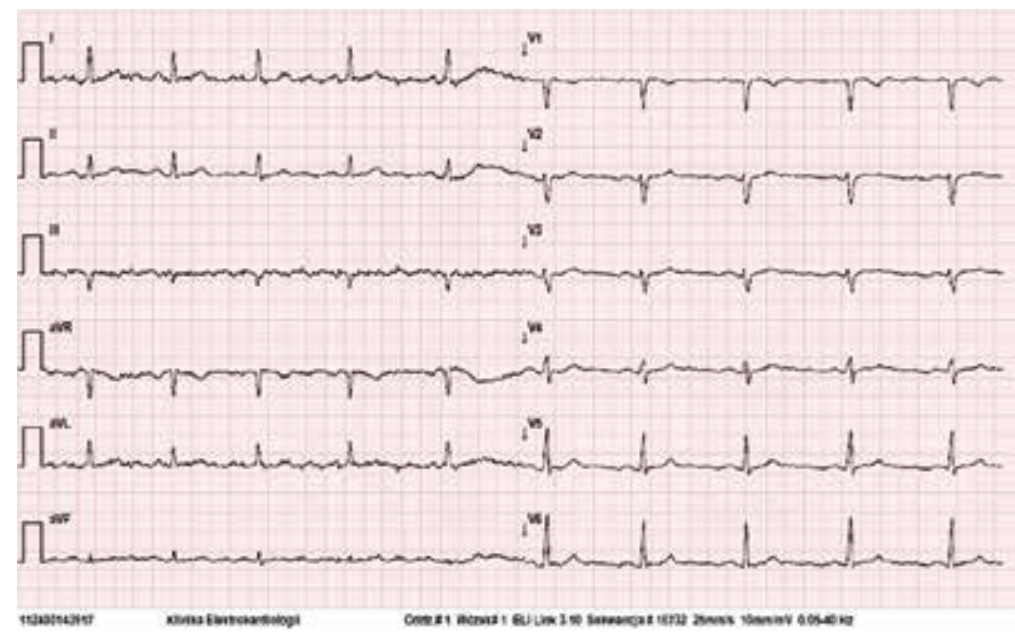

Rycina 3. Standardowy 12-odprowadzeniowy zapis elektrokardiograficzny u pacjenta z chorobą Parkinsona 


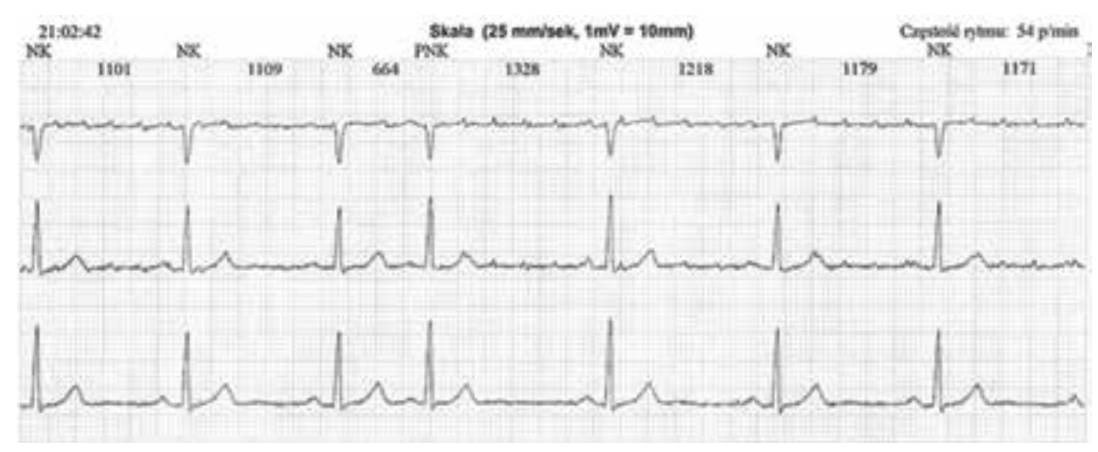

Rycina 4. Fragment zapisu holterowskiego u pacjenta z chorobą Parkinsona

niach II i V1-V6. Jakość zapisu na rycinie 3, wykonanego w momencie, kiedy ruchy mimowolne wynikające z choroby Parkinsona były stosunkowo niewielkie, pozwala zauważyć wyraźne załamki P przed zespołami QRS. Podobny obraz obserwowano w rejestracji EKG metodą Holtera, w którym w kanałach I i II widać liczne zakłócenia sugerujące falę trzepotania przedsionków/częstoskurczu przedsionkowego, natomiast zapis z kanału III wskazuje na pochodzenie zatokowe rytmu. Badanie holterowskie jest obarczone niższym ryzykiem wystąpienia artefaktów u pacjentów z chorobą Parkinsona, ponieważ elektrody są umieszczane tylko na klatce piersiowej (ryc. 4) [3].

\section{Konflikt interesów}

Autorzy deklarują brak konfliktu interesów.

\section{Abstract}

Parkinson's disease is a frequent cause of pitfalls in ECG interpretation. ECG recordings are frequently interpreted as ventricular tachycardia or/and atrial flutter. These ECG findings are in fact provoked by motion artifacts. Case report describes a 59-year-old man with Parkinson's disease in whom wide QRS tachycardia was recognized based on a surface ECG. Patient was referred to a hospital in order to determine indications for an implantable cardioverter-defibrillator implantation. Reanalysis of an electrocardiogram enabled to verify the initial diagnosis.

Key words: ECG, Parkinson's disease, artifacts, tachycardia with wide QRS complexes

Folia Cardiologica 2015; 10, supl. C: 1-3

\section{Piśmiennictwo}

1. Baranowski R., Wojciechwski D., Maciejewska M. (red.). Zalecenia dotyczące stosowania rozpoznań elektrokardiograficznych. Dokument opracowany przez Grupę Roboczą powołaną przez Zarząd Sekcji Elektrokardiologii Nieinwazyjnej i Telemedycyny Polskiego Towarzystwa Kardiologicznego. Kardiol. Pol. 2010; 68 (supl. IV): 1-56.
2. Kozubski W., Liberski P. (red.) Neurologia. Podręcznik dla studentów medycyny. PZWL, Warszawa 2006: 282-286.

3. Houghton A.R., Gray D. EKG jasno i zrozumiale. $\alpha$-medica press, Bielsko-Biała 2005. 